\title{
The role of structuring benthos for juvenile flatfish
}

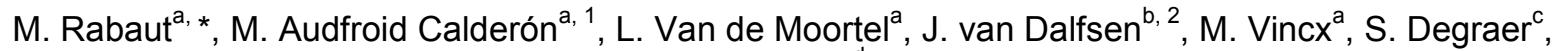 \\ N. Desroy ${ }^{\mathrm{d}}$
}

a Ghent University (UGent), Biology Department, Marine Biology Research Group, Sterre Campus, Krijgslaan 281-S8, B-9000 Ghent, Belgium

${ }^{b}$ IMARES, Ambachtsweg 8a, P.O. Box 57, 1780 Den Helder, The Netherlands

${ }^{c}$ Management Unit of the Mathematical Model of the North Sea, Royal Belgian Institute of Natural Sciences, Gulledelle 100, 1200 Brussels, Belgium

d IFREMER, CRESCO, Laboratoire "Environnement et Ressources Finistère-Bretagne Nord", 38 Rue du Port Blanc, BP 80108, 35801 Dinard, France 38 Rue du Port Blanc, 35800 Dinard, France

${ }^{1}$ Current address: Leibniz Center for Tropical Marine Ecology, Fahrenheitstrasse 6, 28359 Bremen, Germany.

${ }^{2}$ Current address: Deltares, Rotterdamseweg 1852629 HD Delft, The Netherlands.

*: Corresponding author : M. Rabaut, tel.: + 32484500858 ; fax: + 3292648598 ; email address : Marijn.Rabaut@UGent.be

\begin{abstract}
:
Within coastal nurseries, the distribution of juvenile flatfish may depend on small-scale habitat variability. The presence of ecosystem engineers is known to have important impacts in coastal sediments. Lanice conchilega is a well-known marine ecosystem engineer of shallow soft bottom ecosystems, shaping the macrobenthic community and attracting flatfish. The present study examines the relation between juvenile flatfish and $L$. conchilega reefs through two experiments. In a field experiment in the Dutch part of the North Sea, the benthic habitat is evaluated by comparing relative differences in numbers of juvenile flatfish between ecosystem engineered habitats and adjacent bare sand (i.e. non-ecosystem engineered) habitats. The hypothetical shelter seeking behaviour was further examined using stomach content analyses. Results show that juvenile plaice Pleuronectes platessa was the dominant species within the tube worm habitat and the species selects specifically for this biogenic habitat. This selection was explained as feeding behaviour. In a complementary laboratory study, food was excluded and the shelter function of the ecosystem engineered habitat was investigated. This experiment quantifies the selection for this habitat by juveniles of the common sole Solea solea. Results from the flume experiment, manipulating the number of tube worms, show that distribution of sole was not random when current velocities are high. The selected habitat is the one with low density tube worm aggregations. Overall, we conclude that structuring benthos plays an important role for juvenile flatfish, both as refuge and as feeding ground.
\end{abstract}

\section{Highlights}

We test why juvenile flatfish use biogenic habitats. Flume tank results show that young flatfish can use tube worm reefs as shelter. Stomach content of plaice show that juveniles use biogenic habitats to feed. - Tube worm structures of Lanice conchilega serve as shelter and feeding ground.

Keywords: Juvenile flatfish ; Shelter ; Feeding ground ; Lanice conchilega ; Ecosystem engineer ; Pleuronectes platessa 


\section{Introduction}

Structurally complex benthic habitats may play an important role in the ecology and population dynamics of juvenile flatfish species (Pappal, 2006). These systems are heavily used by a variety of taxa, as a consequence of food availability, shelter or simply changing hydrodynamics.

Habitat complexity is the result of different processes. Ecosystem engineers can exert a strong influence on ecosystem properties because of their functional characteristics and this influence exceeds normal expected levels with respect to their mere relative abundance (Hooper et al., 2005). The ecosystem engineers build biogenic structures that add complexity to the habitat. Through these structures, ecosystem engineers modify the hydrodynamic flow regime near the sea floor (Eckman et al., 1981) with significant effects on processes like sedimentation and erosion, food availability driven by hydrodynamic forces and the recruitment, and growth and survival of larvae and/or juveniles (Koenig et al., 2000; Turner et al., 1999).

Animal tubes can cause sediment stabilization as a consequence of several factors (Eckman et al., 1981). By decreasing the water velocity and deflecting the earlier laminar flow around the assemblages, tube worms change the hydrodynamic flow near the sea floor. Flow alterations may have important ecological consequence on sedimentation, food availability, larval and juvenile recruitment, growth and survival. Increased abundances of associated fauna can not only be attributed to enhanced food availability but also to the provision of shelter from larger predators.

The tube building polychaete Lanice conchilega is a dominant ecosystem engineer in coastal marine areas (Rabaut et al., 2007; Van Hoey et al., 2008). The species tends to aggregate in high density patches, with specific biological, physical and temporal features (Rabaut et al., 2009). For the macrobenthic community, the habitat modifying capacity of $L$. conchilega has been suggested to lie in the creation and regulation of safe havens for species, in influencing the interactions between local species and in changing the physical environment (Rabaut et al., 2007; Van Hoey et al., 2008). Patches of high abundance of the species not only attract the aulophora larvae but also hydrodynamically trap sediment (Dittmann, 1999, Eckman, 1983, Heuers et al., 1998). It results in the occurrence of gentle mounds and shallow depressions (Carey, 1987, Féral, 1989, Hartmann-Schröder, 1996, Hertweck, 1995, Zühlke, 2001). Modelling studies suggest that high flow velocities lead to a continuous growth of patches while a mosaic of patches originates at intermediate flow velocities (Heuers et al., 1998). Therefore, the species has been described as an important ecosystem engineer. Its effect on benthic biodiversity has been extensively described (Callaway, 2006; Carey, 1987; Dittmann, 1999; Féral, 1989; Rabaut et al., 2007; Van Hoey, 2006; Zühlke et al., 1998). It was already shown that post-larval Pleuronectes platessa selects for this habitat in intertidal areas, (Rabaut et al., 2010) however, it is not clear whether this habitat plays a role in the distribution and ecology of juvenile flatfish in subtidal areas.

Effects on habitat selection of flatfish are thought to be mainly related to food availability (Beyst et al., 1999; Phelan et al., 2001; Wouters and Cabral, 2009) and therefore the attractiveness of the habitat lies mainly in the increased availability of high quality food items (i.e. larger preys). The shelter function the $L$. conchilega habitat is providing is of potential importance for juvenile flatfish as predation is a major cause of mortality during the early live stages of fishes (Lemke and Ryer, 2006). The demonstrated influence of in situ reefs on juvenile flatfish does, however, not elucidate the extent to which the attraction is due to increased feeding possibilities or to the reefs functioning as a refuge. 
In the present study the selection by flatfish of small scale subtidal habitats formed by tube worm aggregations is tested. Two different flatfish species are used: Plaice (Pleuronectes platessa) and Sole (Solea solea). Pleuronectes platessa is a visual feeder, which mostly takes slow-moving food living on the bottom, but they also feed on active crustaceans. Solea solea, on the other hand, is a nocturnal and olfactrorial feeder with a poorly developed vision which feeds on sessile or barely mobile organisms (Beyst et al., 1999; De Groot, 1971). The size of the mouth, oesophagus and stomach determines the size of the animals that can be ingested. Pleuronectes platessa and $S$. solea have a relatively small mouth and are restricted to the consumption of small-sized prey (Beyst et al., 1999). The diet of both species is therefore quite similar: mostly dominated by polychaetes and, depending on the area, possibly complemented by siphons of the bivalve Spisula spp. (Rijnsdorp \& Vingerhoed, 2001).

Present study tests the selection by flatfish of small scale subtidal habitats formed by tube worm aggregations. A first hypothesis is that prey availability determines juvenile flatfish densities: field observations test the feeding behavior of $P$. platessa inside and outside the structured habitat through gut content analyses (i.e. focus on prey availability as an explanatory factor). The second hypothesis is that structural habitat components are important in determining fish density: laboratory flume tank experiments expose juvenile $S$. solea to different densities of artificial worm tubes at two different current velocities to test the shelter function (excluding food effects).

\section{Methodology}

\subsection{Field sampling and treatment}

The research area was located in the Dutch part of the North Sea in sub-littoral areas $\left(54^{\circ} 00^{\prime} \mathrm{N}, 7^{\circ} 50^{\prime} \mathrm{E}\right.$, just outside the Wadden Sea). Two habitats were identified based on differences in density of L. conchilega in 50 Van Veen grab samples. Only high density samples were qualified as an ecosystem engineered habitat (Rabaut et al., 2009; Rabaut et al., 2007). The densities of the ecosystem engineer in the different habitats (ecosystem engineered habitat versus non-ecosystem engineered habitat) were investigated for each area and prior to further analysis; more that 150 ind. $\mathrm{m}^{-2}$ were considered as high density presence while less than 20 ind $\mathrm{m}^{-2}$ as low density. Differences between habitats were tested in generalized linear models with habitat as a fixed factor and the ecosystem engineer densities as the response variable. The habitats coincided with the areas adjacent to Ameland Island (ecosystem engineered habitat) and Schiermonnikoog island (nonecosystem engineered habitat). The sampling design of two very similar adjacent areas is important to be able to test the correlation with flatfish densities. This approach will provide insight on this appropriate level and extrapolation to larger scales may be difficult (as to avoid using the samples as pseudoreplicates). Flatfish sampling was done at a depth of ca. $6 \mathrm{~m}$ with a 2 m beam trawl deployed form the RV „WR76 Herman Simon". Three tracks were taken in each habitat. Length of each track was approximately $500 \mathrm{~m}$, track lengths were measured in situ and fish densities were recalculated to individuals per $100 \mathrm{~m}^{2}$. Fish were identified, counted and measured on board. Flatfish densities were compared between habitats. Differences were calculated using a generalized linear model in which the fixed factors habitat, age and their interaction effect were related to the flatfish densities (SAS software, proc genmod procedure). The response variables are count data (integers), so the residual error structure follows a Poisson distribution with the variance multiplied by an overdispersion parameter. Because the predictor and the mean response are not linearly related to each other, the relationship was specified by a log link function. The fixed effects structure was reduced in a backward stepwise manner (McCulloch, 2001). 
In the field, flatfish was anaesthetized in a benzocaïne (ethyl amino-4-benzoate) solution to prevent regurgitation of the stomach contents and preserved in an $8 \%$ buffered formalin solution. Flatfishes were divided in two age classes: age class 0 , containing individuals between 5 and $9 \mathrm{~cm}$ and age class 1 containing individuals between 9.1 and $13 \mathrm{~cm}$ (Amara et al., 2001; Beyst et al., 1999). For age class 0, no individuals smaller than $5 \mathrm{~cm}$ were subjected to analysis as these small individuals mainly fed on meiobenthos, while larger individuals shift to macrobenthos (Aarnio et al., 1996). Pleuronectes platessa was the most abundant species for which enough individuals were available to do the analyses. Other flatfish species such as Limanda limanda and Solea solea were caught in low densities. In the laboratory, ten $P$. platessa individuals, per age class and in each habitat were selected for further stomach analyses. All prey items in the stomachs were counted and identified to the lowest possible taxonomic level (further referred to as species). The biomass (mg AFDW) of each prey item present in the stomach as well as the flatfish biomass was measured.

The relative importance of prey in the diet (i.e. stomach content) was expressed as percent of numerical abundance (N\%), weight (G\%), and fullness (FI\%). These percentages express the overall numerical and gravimetric importance of a stomach in a group of samples. N\% and G\% were calculated on non empty stomachs (Frid et al., 1999), while $\mathrm{Fl} \%$ was calculated on all stomachs (including empty). Feeding activity was evaluated by the vacuity index $(\mathrm{V} \%)$. These percentages were calculated for groups of samples as follows:

$\mathrm{N} \%=$ (Number of food items in a stomach / Total number of food items in group) $\times 100$

$\mathrm{G} \%=($ Total biomass in a stomach $) /($ Total biomass in group $) \times 100$

$\mathrm{FI} \%=($ AFDW of stomach content $) /($ AFDW of fish $) \times 100$

$\mathrm{V} \%=$ (Number of empty stomachs in group / Total number of analyzed stomachs in group) $\mathrm{x}$ 100

To analyze more in detail, diet composition, numerical, gravimetric percentages and the frequency of occurrence (FO\%) were further calculated per species within each sampling group. These percentages express the numerical and gravimetric importance on one species within one stomach. Calculations are as follows:

$\mathrm{N}_{\mathrm{i}} \%=$ (Number of prey type i) / (Total number of prey items in the stomach) $\times 100$

$\mathrm{F}_{\mathrm{i}} \%=($ AFDW of prey type i) $/$ (Total AFDW of ingested food $) \times 100$

$\mathrm{FO}_{i} \%=($ Number of stomachs containing prey item $\mathrm{i}) /$ (All stomachs) $\times 100$

As the response variables for the stomach analyses are expressed as relative percentages, the residual error structure was assumed to follow a Binomial distribution. Hence, a generalized linear model was used to evaluate the significance of the fixed effect habitat, age and their interaction effect. The relationship was specified by a logit link function. Differences between habitats were analysed for each age separately (generalized linear model with habitat as a fixed effect). Furthermore, a detailed analysis on species composition was performed. Differences in prey species composition were analysed using multivariate ANOSIM and SIMPER analysis (Clarke and Warwick, 2001). When two factors (habitat and age) were analysed together, two way crossed ANOSIM and SIMPER routines were run (Primer v6).

Prey species composition was analysed on the basis of the frequency of occurrence (FO\%) and the relative contribution of individual prey species to the dissimilarity between groups (SIMPER analysis; two way crossed when two factors involved). These analyses were performed both on numerical and gravimetric indices. Differences in diversity of prey species were based on differences in Shannon Wiener index (Hampel et al., 2005), which was tested with a general linear model if there was homogeneity of variances (Levene"s test) and if the residual error structure followed a Normal distribution (Shapiro-Wilk"s test). If assumptions were not met, non parametric tests on Shannon Wiener index were performed (Wilcoxon). 


\subsection{Laboratory set up}

In the laboratory experiments, the ecosystem engineered habitat was artificially mimicked using false tubes made of a $3 \mathrm{~mm}$ diameter rubber band of $5 \mathrm{~cm}$ in length, coated by inert coarse sand, in order to resemble the flexibility and texture of real $L$. conchilega tubes. Artificial aggregations of tubes were applied in the experimental zone of a flume tank system of $10.5 \mathrm{~m}^{2}$. The experimental area had dimensions of $1 \mathrm{~m}$ length, $0.5 \mathrm{~m}$ width and $15 \mathrm{~cm}$ water height. Three different tube densities were applied next to each other: 3000 tubes. $\mathrm{m}^{-2}$ (treatment 1, T1), 500 tubes. $\mathrm{m}^{-2}$ (treatment 2, T2) and 0 tubes. $\mathrm{m}^{-2}$ (control, C) (Figure 1). These tube densities were based on the biological and physical features of the structures formed (Rabaut et al, 2009). The tubes were spaced randomly as to mimic the irregular spatial arrangement in situ. All treatments had an inert sand $(125 \mu \mathrm{m})$ as substratum layer of $10 \mathrm{~cm}$. Responses were tested for two different water flow velocities: 3 and $15 \mathrm{~m}^{-\mathrm{s}^{-1}}$. For this experiment the flatfish species used is $S$. solea as these were commercially available and aged.

A total of 668 S. solea individuals (9 weeks old; 4-6 cm) were obtained from the hatchery Solea BV in IJmuiden, the Netherlands. Flow-through tanks were used to maintain the juvenile $S$. solea (temperature $14.5+/-1^{\circ} \mathrm{C}$; salinity $34+/-0.1 \mathrm{psu}$ ).

During each experimental run, $200 \mathrm{~S}$. solea individuals were added to the flume. The S. solea individuals were left in the flume tank for $20 \mathrm{~h}$ after which the amount of individuals in each tube density habitat of the experimental section $\left(0.5 \mathrm{~m}^{2}\right)$ was counted (see Figure 1 for experimental set up). This was replicated three times for each water current velocity with the relative position of the treatment compartments changed for each replicate run to avoid position bias in the flume. Replicated G-tests for goodness of fit to chi-square distribution (Sokal and Rohlf, 1995) (also called the log-likelihood ratio test), i.e. 33.33\% of individuals inside each of the three experimental areas, were conducted to determine significant deviations from the expected 1/1/1 (i.e., even) distribution. The general computational formula used was:

$\mathrm{G}=2 \Sigma^{\mathrm{a}} \mathrm{f}_{\mathrm{i}} \ln \left(\mathrm{f}_{\mathrm{i}} / \mathrm{F}_{\mathrm{i}}\right)$

Where $f_{i}$ represented the observed frequencies and $F_{i}$ the expected frequencies.

Pair wise comparisons were performed at a critical probability of $\alpha=\alpha / k$, with $k$ equal to the number of intended tests [Bonferroni approach, Sokal and Rohlf (1995)].

\section{Results}

\subsection{Field study results}

The results from the Van Veen grab analyses, to test differences between habitats with a generalized linear model with habitat as a fixed factor and the ecosystem engineer densities as the response variable, confirm that the densities of $L$. conchilega were significantly higher $(p<0.0001)$ within the ecosystem engineered habitat $\left(242+/-90 \mathrm{SE}\right.$ ind $\left.\mathrm{m}^{-1}\right)$ as compared to the very low densities outside $\left(12+/-1 \mathrm{SE}\right.$ ind $\left.\mathrm{m}^{-1}\right)$. Results from the beam trawl tracks showed that densities of $P$. platessa are significantly higher within the $L$. conchilega ecosystem engineered habitats as compared to the densities outside (Figure 2, Table 1). No age effects or interactions were found (Table 1). Solea solea was only found in low densities: 17 individuals in the L. conchilega ecosystem engineered area (all in the same beam trawl sample) and 1 individual outside. 
Turning to stomach contents, both age classes had a higher fullness index and gravimetrically stomachs contained more food within the ecosystem engineered habitat (Figure 3; Table 2). Nonetheless, stomachs seemed to have more prey items and less empty stomachs in the non-ecosystem engineered area: $27 \%$ of the stomachs were empty for individuals caught in the ecosystem engineered habitat against only $10 \%$ outside.

Analyzing the prey item composition, the two way crossed SIMPER results show a large dissimilarity between prey item assemblage caught in areas with and without ecosystem engineer (Table 3). Moreover, two way crossed ANOSIM results show that there was a significant habitat and age effect, both numerically and gravimetrically (Table 3). Based on the frequency of occurrence (FO\%) and on multivariate analyses on $\mathrm{G} \%$ and $\mathrm{N} \%$ data, the four most important preys were Spio spec., L. conchilega, Pontocrates altamarinus and Nephtys hombergii (Table 4).

Spio spec. was an important prey for $P$. platessa in the non-ecosystem engineered habitat (both numerically and gravimetrically), while $L$. conchilega seemed to be an important prey in the ecosystem engineered habitat. No significant effects were found for $P$. altamarinus and $N$. hombergii (Figure 4, Table 4). Differences because of age classes were found for Spio spec., which occurred in significantly higher densities in age class $0(N \%, p=0.0266 ; G \%$, $p=0.002)$ and for $L$. conchilega, which was more frequently eaten by $P$. platessa of age class 1 (only gravimetrically, $p=0.0221$ ). In terms of diversity of species, no significant differences were found between habitats $(p=0.2633)$ or ages $(p=0.5094)$.

\subsection{Laboratory results}

Flume experiments showed that $S$. solea was found in higher densities in the lower tube density habitat of 500 tubes. $\mathrm{m}^{-2}$ as compared to the non-engineered habitat $(C)$ and to the high tube density habitat of 1000 tubes. $\mathrm{m}^{-2}$ (Figure 5; table 5). There was no significant difference in selection found between the control area and the high tube density habitat $(p>0.05)$. The differences in flatfish densities were only significant when current velocity is high $\left(15 \mathrm{~m} \mathrm{~s}^{-1}\right)$, no statistical significant selection could be found with low water current velocities $\left(3 \mathrm{~m} \mathrm{~s}^{-1}\right)$ (Figure 5; Table 5).

\section{Discussion}

Results show that flatfish species occur in higher densities when the habitat is shaped by $L$. conchilega than in non-engineered habitats. The selection for these habitats by flatfish has been confirmed in several studies (Amara et al., 2001; Rabaut et al., 2010). Shucksmith et al. (2006) indicate that adult $P$. platessa densities correlate specifically with $L$. conchilega and Chaetopterus spec. Pleuronectes platessa has been described earlier as being tightly associated with assemblages containing structuring epifauna such as hydroids, Alcyonium digitum, A. diaphanum and Flustra foliacea (Kaiser et al., 1999). On the contrary, some structured habitats such as vegetated habitats can have a negative effect on feeding and growth as indicated for juvenile European flounder (Platichthys flesus) in eelgrass environments (Gronkjaer et al., 2007). Our analyses suggest that there is no unique reason why juvenile flatfish is found in higher densities in the structured habitats but increased food availability and shelter may trigger juvenile flatfish to reside between $L$. conchilega tubes. However, the use of different species and both laboratory and in situ experiments has limitations (see below). Juveniles of $P$. platessa showed a clear feeding advantage when they were found within the ecosystem engineered habitat. Plaice has a higher fullness index within the ecosystem engineered areas. A higher fullness is thought to be a good predictor of growth (Tarpgaard et al., 2005). The higher gut fullness is also reflected in the gravimetric 
percentage. The numerical percentage, however, shows a totally opposite trend. The higher number of prey items in areas without the ecosystem engineer was fully attributed to Spio spec. It seems that in the absence of the ecosystem engineer $L$. conchilega, $P$. platessa turns to Spio spec. as main prey item. However, Spio spec. are described as positively associated with L. conchilega (Rabaut et al., 2007), but it appears that $P$. platessa feeds less on it when $L$. conchilega is available as prey. Although Pontocrates altamarinus is known to be negatively associated with $L$. conchilega (Rabaut et al., 2007), it occurs more frequently as prey in flatfish caught in $L$. conchilega aggregations. The main advantage seems to be that juvenile flatfish fill their stomach with larger items, i.a. the tube worm $L$. conchilega itself. On the contrary, the vacuity index is higher in the ecosystem engineered habitat and the number of prey items is lower implying that the feeding behavior changes as a function of the presence of the bio-engineered habitat. Without the structured habitat, juvenile flatfish seems to feed on what can be found, which means constant foraging on smaller prey items. In the $L$. conchilega habitat, the flatfish becomes more selective for larger food items, leading to a lower feeding activity, a lower number of prey items but a higher fullness index and more biomass found in non-empty stomachs. This can potentially explain to some extent the higher flatfish densities within the ecosystem engineered habitat. Differences in growth rate are related to differences in food composition and availability as well (Gronkjaer et al., 2007; van der Veer and Witte, 1993). Pleuronectes platessa generally prefers to consume common species (Lockwood, 1984; Wyche and Shackley, 1986). Therefore, we hypothesize that the selectivity of juvenile flatfish to feed within biogenically created habitats is a result of their feeding behaviour which is generally opportunistic (Beyst et al., 1999; Dolbeth et al., 2008; Holmes and Gibson, 1983). Increasing abundances of relatively easy-to-catch prey attract these opportunistic feeders. Besides the feeding advantage, our experiment shows that juvenile flatfish such as $S$. solea seems to select for the engineered habitat, even if food is absent. The selected habitat turns out to be the low density aggregations

(500 ind. $\mathrm{m}^{-2}$ ). It is important to mention here that the laboratory experiment and the field observations are aimed at different flatfish species. In the field observation, larger individuals in lower density tube worm habitats use the habitat to feed, while the laboratory experiment shows specific behavior of very young S. solea individuals in higher tube worm reefs. Hence, the results are complementary as we can conclude that both food and other aspects can attract juvenile flatfish. However, we have no information on whether juvenile $S$. solea do feed in the ecosystem engineered habitat and it is uncertain whether juvenile $P$. platessa would use the tube worm reefs as shelter.

Further, in our experiment the highest tube densities of 3000 ind $\mathrm{m}^{-1}$ to which the species are exposed to in this experiment are too high to be selected by S. solea. The length of the 9week old S.solea $(4-6 \mathrm{~cm})$ is small enough to occupy the space between the tubes as several individuals were found there during the experiment. Nevertheless, the higher flatfish densities in the lower density reef suggest that when tube densities are very high, the space between tubes might become the limiting factor and make this high density habitat less attractive. The lower tube density habitat harbored more S. solea than the control area, showing that $S$. solea is able to use the low density reefs.

The low tube density habitat was most likely characterized by more favorable hydrodynamic conditions. The lower density reefs become more selected than the control zones only when current velocity increases, suggesting that $S$. solea uses the ecosystem engineered habitat only when high water current velocities exist. It is known that biota can affect local sediment transportation and can stabilize or destabilize the environment. It is widely thought that animal tubes stabilize sediments by altering the character of near-bed flow. In some cases, the region of maximum turbulent kinetic energy and shear stress production occurs away from the bed (this is the so-called "skimming flow") (Morris, 1950). In a study by Friedrichs et al. (2000), it was described that a skimming flow was created. This ecosystem engineering effect is considered as an important factor for the habitat selection of $S$. Solea and $P$. 
platessa. The inclusion of the abundance of benthic fauna in habitat suitability models has been proven as important in distribution predictions (Le Pape et al., 2007; Nicolas et al., 2007) and Ryer et al. (2004) suggest incorporating considerations of emergent structures of low-relief benthic habitats that impart structural complexity into models for flatfish habitatsuitability.

In conclusion, structured biogenic habitats within nursery areas seem to be attractive for juvenile flatfish and play an important role in juvenile flatfish distribution. Effects on habitat selection by flatfish seem to be partially related to food availability and the attractiveness of the habitat mainly lies in the increased availability of high quality food items (i.e. larger preys). The shelter provided by the biogenic structure, however, seems not unimportant. Interestingly, S. solea selects lower density reefs over very high density reefs, which is analogous to what has been described for the macrobenthic community. Both shelter function and food availability seems to be of more importance for smaller (age class 0 ) flatfish. The results of our study are complementary and highlight the importance of biogenic habitats within flatfish nursery areas in general and shows that $L$. conchilega tube worm aggregations can function both as refuge and as feeding area.

\section{Acknowledgments}

This research was carried out within the WESTBANKS project (understanding benthic, pelagic and air-borne ecosystem interactions in shallow coastal seas; http://www.vliz.be/projects/westbanks) which is supported by the Belgian Science Policy (BELSPO; contract no. SD/BN/01). We further would like to thank the master and crew of the $R V$,Herman Simon" for their patient and skilful help during sampling. We thank also the UMR CRESCO for the use of and logistic support for the flume tank facilities. We are indebted to Jezabel Lamoureux for technical support. We are very grateful for the assistance during AFDW measurements by Danielle Schram. We are indebted to Liesbeth Hiele for the valuable linguistic comments. The authors acknowledge the two anonymous reviewers and the editors for the valuable comments. The first author is particularly grateful for the fruitful discussions and useful comments provided during the $8^{\text {th }}$ International Flatfish Symposium (IJmuiden, The Netherlands) by several researchers.

\section{References}

Aarnio, K., Bonsdorff, E., Rosenback, N., 1996. Food and feeding habits of juvenile flounder Platichthys flesus (L.) and turbot Scophtalmus maximus (L.) in the Aland archipelago, northern Baltic Sea. J. Sea Res. 36, 311-320.

Amara, R., Laffargue, P., Dewarumez, J.M., Maryniak, C., Lagardere, F., Luczac, C., 2001. Feeding ecology and growth of O-group flatfish (sole, dab and plaice) on a nursery ground (Southern Bight of the North Sea). J. Fish Biol. 58, 788-803.

Beyst, B., Cattrijsse, A., Mees, J., 1999. Feeding ecology of juvenile flatfishes of the surf zone of a sandy beach. J. Fish Biol. 55, 1171-1186.

Callaway, R., 2006. Tube worms promote community change. Mar. Ecol. Prog. Ser. 308, 4960.

Carey, D.A., 1987. Sedimentological effects and palaeoecological implications of the tubebuilding polychaete Lanice conchilega Pallas. Sedimentology. 34, 49-66. 
Clarke, K.R., Warwick, R.M. 2001. Change in marine communities: An approach to statistical analysis and interpretation. PRIMER-E Ltd. Plymouth Marine Laboratory, Plymouth.

De Groot, S.J., 1971. On the interrelationships between morphology of the alimentary tract, food and feeding behaviour in flatfishes (Pisces: Pleuronectiformes). J. Sea Res. 5: 121-196.

Denis, L., Desroy, N., Ropert, M., 2007. Ambient flow velocity and resulting clearance rates of the terebellid polychaete Lanice conchilega (Pallas, 1766). J. Sea Res. 58, 209-219.

Dittmann, S., 1999. Biotic interactions in a Lanice conchilega-dominated tidal flat, in: S. Dittmann (Eds), The Wadden Sea ecosystem: Stability properties and mechanisms pp. 153162.

Dolbeth, M., Martinho, F., Leitao, R., Cabral, H., Pardal, M.A., 2008. Feeding patterns of the dominant benthic and demersal fish community in a temperate estuary. J. Fish Biol. 72, 2500-2517.

Eckman, J.E., Nowell, A.R.M., Jumars, P.A., 1981. Sediment destabilization by animal tubes. J. Mar. Res. 39, 361-374.

Féral, P., 1989. Biosedimentological implications of the polychaete Lanice conchilega (Pallas) on the intertidal zone of two Norman sandy shores (France). B. Soc. Geol. Fr. 5, 1193-1200.

Frid, C.L.J., Clark, R.A., Hall, J.A., 1999. Long-term changes in the benthos on a heavily fished ground off the NE coast of England. Mar. Ecol. Prog. Ser. 188, 13-20.

Friedrichs, M., Graf, G., Springer, B., 2000. Skimming flow induced over a simulated polychaete tube lawn at low population densities. Mar. Ecol. Prog. Ser. 192, 219-228.

Gage, J.D., 1977. Structure of the abyssal macrobenthic community in the Rockall Trough, in: B.F. Keegan, P.O. Ceidigh and P.J.S. Boaden (Eds), Biology of benthic organisms. Pergamon Press, Oxford, pp. 630.

Gronkjaer, P., Carl, J.D., Rasmussen, T.H., Hansen, K.W., 2007. Effect of habitat shifts on feeding behaviour and growth of 0 year-group flounder Platichthys flesus (L.) transferred between macroalgae and bare sand habitats. J. Fish Biol. 70, 1587-1605.

Hampel, H., Cattrijsse, A., Elliott, M., 2005. Feeding habits of young predatory fishes in marsh creeks situated along the salinity gradient of the Schelde estuary, Belgium and The Netherlands. Helgol. Mar. Res. 59, 151-162.

Holmes, R.A., Gibson, R.N., 1983. A comparison of predatory behaviour in flatfish. Anim. Behav. 31, 1244-1255.

Hooper, D.U., Chapin, F.S., Ewel, J.J., Hector, A., Inchausti, P., Lavorel, S., Lawton, J.H., Lodge, D.M., Loreau, M., Naeem, S., Schmid, B., Setala, H., Symstad, A.J., Vandermeer, J., Wardle, D.A., 2005. Effects of biodiversity on ecosystem functioning: A consensus of current knowledge. Ecol. Monogr. 75, 3-35.

Kaiser, M.J., Rogers, S.I., Ellis, J.R., 1999. Importance of benthic habitat complexity for demersal fish assemblages. Am. Fish. Soc. Symp. 22, 212-223.

Koenig, C.C., Coleman, F.C., Grimes, C.B., Fitzhugh, G.R., Scanlon, K.M., Gledhill, C.T., Grace, M., 2000. Protection of fish spawning habitat for the conservation of warm-temperate reef-fish fisheries of shelf-edge reefs of Florida. Bull. Mar. Sci. 66, 593-616. 
Le Pape, O., Baulier, L., Cloarec, A., Martin, J., Le Loc'h, F., Desaunay, Y., 2007. Habitat suitability for juvenile common sole (Solea solea, L.) in the Bay of Biscay (France): A quantitative description using indicators based on epibenthic fauna. J. Sea Res. 57, 126-136.

Lemke, J.L., Ryer, C.H., 2006. Risk sensitivity in three juvenile (Age-0) flatfish species: Does estuarine dependence promote risk-prone behavior? J. Exp. Mar. Biol. Ecol. 333, 172-180.

Lockwood, S.J., 1984. The daily food intake of 0-group Plaice (Pleuronectes platessa) under natural conditions: Changes with size and season. Journal Du Conseil. 41, 181-193.

McCulloch, C.E. 2001. Generalized, Linear, and Mixed Models. Wiley.

Morris, H.M., 1950. A New Concept of Flow in Rough Conduits. T. Am. Soc. Civ. Eng. 120, 373-398.

Nicolas, D., Le Loc'h, F., Desaunay, Y., Hamon, D., Blanchet, A., Le Pape, O., 2007. Relationships between benthic macrofauna and habitat suitability for juvenile common sole (Solea solea, L.) in the Vilaine estuary (Bay of Biscay, France) nursery ground. Estuar. Coast. Shelf Sci. 73, 639-650.

Pappal, A.L., 2006. Cobble habitat preferences of juvenile winter flounder. University of Massachusetts Dartmouth, MSc thesis.

Phelan, B.A., Manderson, J.P., Stoner, A.W., Bejda, A.J., 2001. Size-related shifts in the habitat associations of young-of-the-year winter flounder (Pseudopleuronectes americanus): Field observations and laboratory experiments with sediments and prey. J. Exp. Mar. Biol. Ecol. 257, 297-315.

Rabaut, M., Guilini, K., Van Hoey, G., Vincx, M., Degraer, S., 2007. A bio-engineered softbottom environment: The impact of Lanice conchilega on the benthic species-specific densities and community structure. Estuar. Coast. Shelf Sci. 75, 525-536.

Rabaut, M., Van de Moortel, L., Vincx, M., Degraer, S., 2010. Biogenic reefs as structuring factor in Pleuronectes platessa (Plaice) nursery. J. Sea Res. 64, 102-106.

Rabaut, M., Vincx, M., Degraer, S., 2009. Do Lanice conchilega (sandmason) aggregations classify as reefs? Quantifying habitat modifying effects. Helgol. Mar. Res. 63, 37-46.

Rijnsdorp, A.D., Vingerhoed, B., 2001. Feeding of plaice Pleuronectes platessa L. and sole Solea solea (L.) in relation to the effects of bottom trawling. J. Sea Res. 45, 219-229.

Ryer, C.H., Stoner, A.W., Titgen, R.H., 2004. Behavioral mechanisms underlying the refuge value of benthic habitat structure for two flatfishes with differing anti-predator strategies. Mar. Ecol. Prog. Ser. 268, 231-243.

Shucksmith, R., Hinz, H., Bergmann, M., Kaiser, M.J., 2006. Evaluation of habitat use by adult plaice (Pleuronectes platessa L.) using underwater video survey techniques. J. Sea Res. 56, 317-328.

Sokal, R.R., Rohlf, F.J. 1995. Biometry. Freeman, New York.

Tarpgaard, E., Mogensen, M., Gronkjaer, P., Carl, J., 2005. Using short-term growth of enclosed 0-group European flounder, Platichthys flesus, to assess habitat quality in a Danish bay. J. Appl. Ichthyol. 21, 53-63. 
Turner, S.J., Thrush, S.F., Hewitt, J.E., Cummings, V.J., Funnell, G., 1999. Fishing impacts and the degradation or loss of habitat structure. Fisheries Management \& Ecology. 6, 401420.

van der Veer, H.W., Witte, J.I.J., 1993. The 'maximum growth/optimal food condition' hypothesis: A test for 0-group plaice Pleuronectes platessa in the Dutch Wadden Sea. Mar. Ecol. Prog. Ser. 101, 81-90.

Van Hoey, G., 2006. Spatio-temporal variability within the macrobenthic Abra alba community, with the emphasis on the structuring role of Lanice conchilega. Ghent University (UGent), PhD thesis, Ghent.

Van Hoey, G., Guilini, K., Rabaut, M., Vincx, M., Degraer, S., 2008. Ecological implications of the presence of the tube-building polychaete Lanice conchilega on soft-bottom benthic ecosystems. Mar. Biol. 154, 1009-1019.

Wennhage, H., 2002. Vulnerability of newly settled plaice (Pleuronectes platessa L.) to predation: Effects of habitat structure and predator functional response. J. Exp. Mar. Biol. Ecol. 269, 129-145.

Wouters, N., Cabral, H.N., 2009. Are flatfish nursery grounds richer in benthic prey? Estuarine, Coastal and Shelf Science. 83, 613-620.

Wyche, C.J., Shackley, S.E., 1986. The feeding ecology of Pleuronectes platessa (L.), Limanda limanda (L.) and Scophthalmus rhombus (L.) in Carmarthen bay, South-Wales, UK. J. Fish Biol. 29, 303-311.

Zühlke, R., Blome, D., Heinz van Bernem, K., Dittmann, S., 1998. Effects of the tube-building polychaete Lanice conchilega (Pallas) on benthic macrofauna and nematodes in an intertidal sandflat. Senckenb. Marit. 29, 131-138. 


\section{Tables}

Table 1. Differences in flatfish densities between age, habitat and interaction effect ( $p$ values). Statistical test: generalized linear model to compare densities (poisson distribution; proc genmod procedure in SAS software). Asterisks indicate significant differences. Differences between „Habitats" refer to the differences between ecosystem engineered and non-ecosystem engineered habitats.

\begin{tabular}{lccc} 
& Habitat & Habitat x Age & Age \\
\hline Both age classes & $0.0001^{*}$ & 0.9699 & 0.1949 \\
Age class 0 & $0.0024^{*}$ & - & - \\
Age class 1 & $0.0076^{*}$ & - & - \\
\hline
\end{tabular}

Table 2. Differences ( $p$-values) in stomach contents between ecosystem engineered and non-ecosystem engineered habitats expressed as $\mathrm{FI} \%$ (fullness index), G\% (proportional gravimetric values) and $\mathrm{N} \%$ (proportional numerical values). Statistical test: generalized linear model to compare densities (binomial distribution; proc genmod procedure in SAS software).

\begin{tabular}{cccc}
\hline & $\mathrm{Fl} \%$ & $\mathrm{G} \%$ & $\mathrm{~N} \%$ \\
\hline Age class 0 & $0.0002^{*}$ & $0.0005^{*}$ & $0.0030^{*}$ \\
Age class 1 & $0.0089^{*}$ & 0.2806 & 0.1419 \\
\hline
\end{tabular}

Table 3. Prey species community analysis. ANOSIM (R-values) and SIMPER dissimilarities between prey communities of flatfish caught inside ecosystem engineered habitats and those outside and between age classes (two way crossed analysis). ANOSIM R and correspondent p-values are given for numerical $(\mathrm{N} \%)$ and for gravimetric $(\mathrm{G} \%)$ percentages. SIMPER dissimilarities indicate differences in prey composition. Significant differences are indicated with an asterisk.

\begin{tabular}{cccccccc}
\hline & \multicolumn{3}{c}{$\mathbf{N} \%$} & & \multicolumn{3}{c}{$\mathbf{G} \%$} \\
\cline { 2 - 4 } \cline { 6 - 8 } & $\mathbf{R}$ & $\mathbf{p}$ & dissimalarity & & $\mathbf{R}$ & $\mathbf{p}$ & dissimalarity \\
\hline age & 0.351 & $0.005^{*}$ & 71.46 & & 0.311 & $0.001^{*}$ & 73.76 \\
habitat & 0.581 & $0.001^{*}$ & 90.57 & & 0.507 & $0.001^{*}$ & 94.12 \\
\hline
\end{tabular}


Table 4. Most dominant prey items in ecosystem engineered and non-ecosystem engineered habitat. Importance of prey items is based on frequency of occurrence (FO\%), species contribution to the dissimilarity of community composition between habitats (two way crossed SIMPER). Numerical and gravimetric differences of prey species between habitats is indicated with significance level (asterisks indicate significant differences).

\begin{tabular}{|c|c|c|c|c|c|c|}
\hline \multirow[b]{2}{*}{ species } & \multicolumn{2}{|c|}{$\mathrm{FO} \%$} & \multicolumn{2}{|c|}{ SIMPER } & \multicolumn{2}{|c|}{ p level } \\
\hline & without ecosystem engineer & with ecosystem engineer & $\%$ contribution ( $\mathrm{N} \%)$ & $\%$ contribution (G\%) & $\mathrm{N} \%$ & $\mathrm{G} \%$ \\
\hline Spio sp. & 68.75 & 25 & 39.51 & 39.56 & $<0.0001^{*}$ & $<0.0001^{*}$ \\
\hline L. conchilega & 6.25 & 16.67 & 33.43 & 24.75 & $<0.0001^{*}$ & $<0.0001^{*}$ \\
\hline P. altamarinus & 10 & 11.11 & 11.21 & 0.05 & 0.069 & 0.9828 \\
\hline N. hombergii & 21.25 & 0 & 3.27 & 2.8 & 0.2926 & 0.0501 \\
\hline
\end{tabular}


Table 5. Significance levels for differences in flatfish densities between habitats. No significant differences are found with low current velocity while with high water current velocity, the juvenile $S$. solea selects clearly the intermediate tube density ( $T 2=500$ tubes $\mathrm{m}^{-}$ ${ }^{2}$ ) over both bare sand $(C=$ no tubes $)$ and very high tube density $\left(T 1=3000\right.$ tubes $\left.\mathrm{m}^{-2}\right)$.

\begin{tabular}{ll}
\hline $3 \mathrm{~cm} . / \mathrm{sec}$ & $\mathrm{T} 2>\mathrm{T} 1: G \mathrm{p}=2.06, P=0.151$ \\
& $\mathrm{C}>\mathrm{T} 2: G \mathrm{p}=0.63, P=0.425$ \\
& $\mathrm{C}>\mathrm{T} 1: G \mathrm{p}=4.971, P=0.026$ \\
\hline $15 \mathrm{~cm} . / \mathrm{sec}$ & $\mathrm{T} 2>\mathrm{T} 1: G \mathrm{p}=8.6, P=0.003^{*}$ \\
& $\mathrm{~T} 2>\mathrm{C}: G \mathrm{p}=7.1, P=0.007^{*}$ \\
& $\mathrm{C}>\mathrm{T} 1: G \mathrm{p}=0.071, P=0.789$ \\
\hline
\end{tabular}

\section{Figures}

Figure 1. Experimental set up. Above: cross section of flume tank (total flume tank length: $21 \mathrm{~m}$, width $50 \mathrm{~cm}$ ). Below: experimental section seen from above. $200 \mathrm{~S}$. solea individuals are left for $20 \mathrm{~h}$ in the total flume tank after which densities in the experimental section are counted. Three different tube densities were applied next to each other: 3000 tubes. $\mathrm{m}^{-2}$ (treatment 1, T1), 500 tubes. $\mathrm{m}^{-2}$ (treatment 2, T2) and 0 tubes. $\mathrm{m}^{-2}$ (control, C). The tubes were spaced randomly as to mimic the irregular spatial arrangement in situ. All treatments had an inert sand $(125 \mu \mathrm{m})$ as substratum layer of $10 \mathrm{~cm}$. Responses were tested for two different water flow velocities: 3 and $15 \mathrm{~m}_{\text {. }}{ }^{-1}$. Tests were replicated three times for each water current velocity with the relative position of the treatment compartments changed for each replicate run to avoid position bias in the flume.

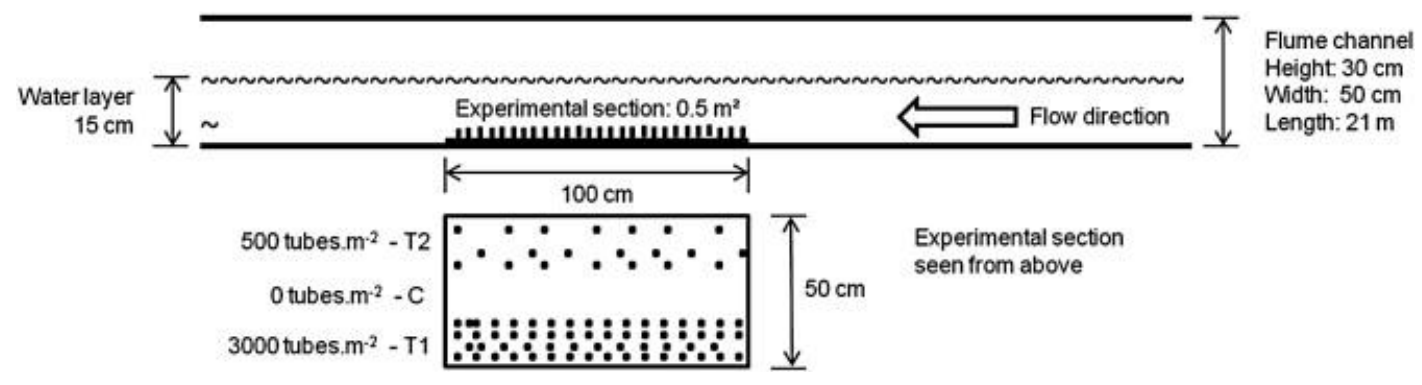

Figure 2. Flatfish densities. White bars represent flatfish densities in non- ecosystem engineered habitat; black bars represent flatfish densities in ecosystem engineered habitat (standard error bars are indicated).

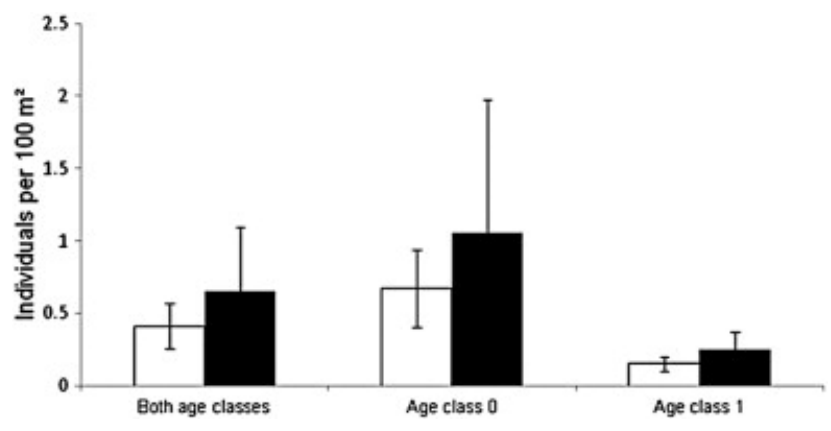


Figure 3. Overall stomach analysis per age class of $P$. platessa representing fullness index (FI\%) (left), proportional gravimetric differences (G\%) (middle) and proportional numerical differences $(\mathrm{N} \%)$. Non-ecosystem engineered habitat is represented with white bars; ecosystem engineered habitat is visualized as black bars.
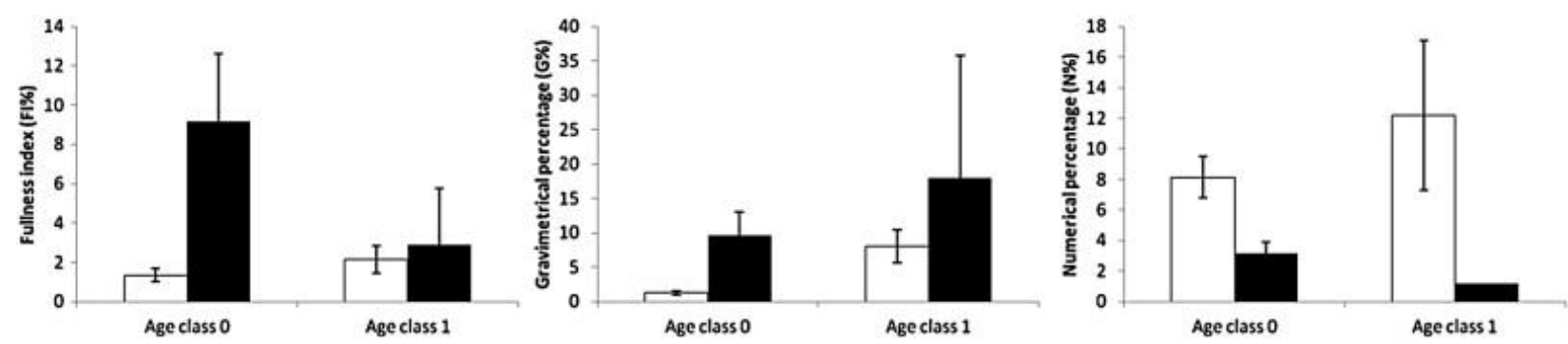

Figure 4. Stomach content: prey species analysis. Numerical (N\%) and gravimetric (G\%) differences for the most important prey species are represented. Non-ecosystem engineered habitat is represented with whit bars; ecosystem engineered habitat is visualized as black bars. Significant differences between habitats are indicated with a star

Age class 0
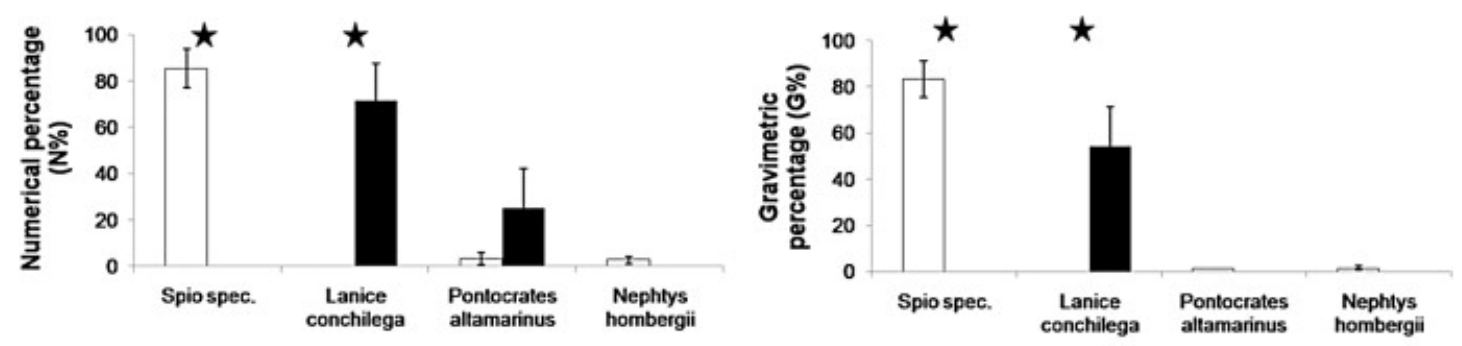

Age class 1
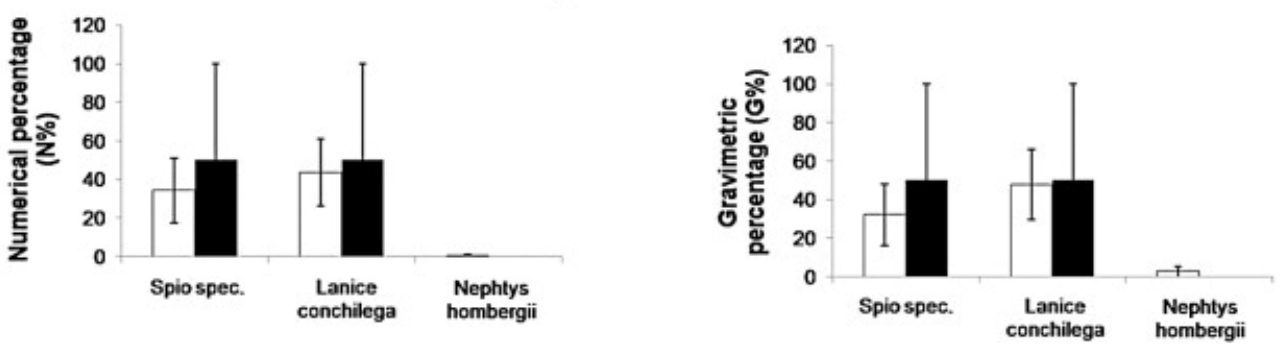
Figure 5. Relative distribution over different habitats $\left(\mathrm{T} 1=3000\right.$ tubes $\mathrm{m}^{-2} ; \mathrm{T} 2=500$ tubes $\mathrm{m}^{-}$ ${ }^{2} ; \mathrm{C}=$ no tubes). Differences between habitats shown for high water current velocity $\left(15 \mathrm{~m} \mathrm{~s}^{-}\right.$ 1; black) and low water current velocity $\left(3 \mathrm{~m} \mathrm{~s}^{-1}\right.$; white). Habitat selection is more pronounced when water current velocities are high.

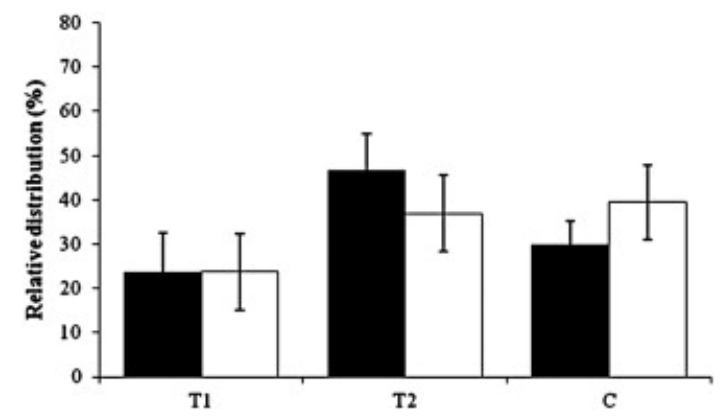

